\title{
A Novel Asymmetric Chair-like Hydroxyl-bridged Tetra-copper Compound: Synthesis, Supramolecular Structure and Magnetic Property
}

Xiao-Feng Wang ${ }^{\mathrm{a}, *}$, Ke-Jie Du ${ }^{\mathrm{a}}$, Hong-Qing Wang ${ }^{\mathrm{a}}$, Xue-Li Zhang ${ }^{\mathrm{b}, \star}$ and Chang-Ming $\mathrm{Nie}^{\mathrm{a}}$

\begin{abstract}
:
A new polynuclear $\mathrm{Cu}(\mathrm{II})$ compound, $\left[\mathrm{Cu}_{4}(\mathrm{bpy})_{4}(\mathrm{OH})_{4}\left(\mathrm{H}_{2} \mathrm{O}\right)(\mathrm{BTC})\right] \mathrm{NO}_{3} \cdot 8 \mathrm{H}_{2} \mathrm{O}$ (1), was prepared by self-assembly from the solution of copper(II) nitrate and two kinds of ligands, 2,2'-bipyridine (bpy) and benzene-tricarboxylic acid $\left(\mathrm{H}_{3} \mathrm{BTC}\right)$. Single crystal structure analysis reveals that 1 features a rare asymmetric chair-like hydroxyl-bridged tetra-copper cluster: $\left[\mathrm{Cu}_{4}(\mathrm{OH})_{4}\right]$ core along with one $\mathrm{H}_{2} \mathrm{O}$ and one $\mathrm{BTC}^{3-}$ occupied each terminal coordinated site. In addition, the magnetic property has been investigated.
\end{abstract}

Keywords: Copper $\bullet$ Asymmetric tetranuclear cluster $\bullet X$-ray diffraction $\bullet$ Thermal stability $\bullet$ Magnetic property 


\section{Introduction}

The discrete poly-nuclear metallic cluster-based coordination complexes attract widespread attentions not only derived from their potential applications as functional materials in catalysis [1], optics [2,3], electron transport [4] and molecule-based magnets [5-7], but also from their relatively simple core structures, which are provided the pretty better opportunities to deeply understand its structure-properties relationship. Therefore, a numerous polynuclear cluster materials, especially molecular-based magnets, have been harvested to employ the small ligands (which offer the shorter and stronger magnetic exchange pathways [8-10], such as formic, cyanide, halogen and azide), and have exhibited the interesting magnetization [11-13]. However, the slightly structural changing of the molecular-based materials might perform intriguing varieties of the magnetic phenomena. In many cases, the counter-ions, co-ligands and the lattice guest species also put effects in the magnetic performances, which commonly through the supramolecular interactions including the hydrogen bond or $\pi-\pi$ stacking, besides the spin ground states and minimal spin polytopes constitutes of the central transition metal ions [14-17]. Consequently, it is necessary to rational prepare and investigate magnetic properties of more complexes and its variant analogues in order to correspondingly establish the unique structural-activity relationship for the molecular magnetism.

Among the commonly used assemble modules, the hydroxyl feature smaller donor atom size and routine $\left(\mu_{2^{-}}\right.$or $\left.\mu_{3^{-}}\right)$bridging models, so the hydroxyl-bridged metal polynuclear clusters are the suitable candidates to investigate the magneto-structural correlation. Currently, a series poly-nuclear copper complexes based well-known hydroxyl-bridged dinuclear $\left[\mathrm{Cu}\left(\mu_{2}-\mathrm{OH}\right)_{2} \mathrm{Cu}\right]$ units had been step-like synthesized and characterized: monomer, dimmer (also considered as chair-like type tetra-copper complex) and trimer of dicopper $\left[\mathrm{Cu}(\mathrm{OH})_{2} \mathrm{Cu}\right]$ cluster $[18,19]$.

However, the chair-like type hydroxyl-bridged tetra-copper compounds have been prepared are scant and all are symmetric cluster [20,21]. Herein, we report a new asymmetric chair-like type tetra-nuclear copper complex, $\left[\mathrm{Cu}_{4}(\mathrm{bpy})_{4}(\mathrm{OH})_{4}\left(\mathrm{H}_{2} \mathrm{O}\right)(\mathrm{BTC})\right] \mathrm{NO}_{3} \cdot 8 \mathrm{H}_{2} \mathrm{O}(1$, bpy $=2,2$ '-bipyridine and $\mathrm{H}_{3} \mathrm{BTC}$ = benzene tricarboxylic acid), which can be readily ambient synthesized and further characterized by powder X-ray diffraction (PXRD), elemental analysis (EA), thermogravimetry analysis (TGA) and differential scanning calorimetry (DSC). 


\section{Experimental}

\subsection{Materials and Physical Methods}

Chemical reagents were commercially purchased and used without further purification. The $\mathrm{C}, \mathrm{H}$ and $\mathrm{N}$ elemental analyses were carried out with a Vario EL elemental analyzer. The Fourier Transform infrared (FT-IR) spectrum was recorded on a Shimadzu IRPrestige-21 spectrometer using $\mathrm{KBr}$ pellets. Thermogravimetric measurements were carried out in a nitrogen stream with a Netzsch STA409PC apparatus with a heating rate of $10{ }^{\circ} \mathrm{C} \cdot \mathrm{min}^{-1}$. Diffraction studies on single crystals were conducted with a Bruker SMART APEX-II CCD diffractometer diffractometer equipped with graphite-monochromated Mo-K $\alpha$ radiation $(\lambda=0.71073 \AA)$ at $296 \mathrm{~K}$ using an $\omega-2 \theta$ scan mode. Powder X-ray diffraction (PXRD) data were collected on a Rigaku D/max 2200 diffractometer with $\mathrm{Cu}-\mathrm{K} \alpha$ radiation $(\lambda=1.5418 \AA)$. Variable-temperature magnetic susceptibility measurements were performed using a Quantum Design MPMS superconducting quantum interference device (SQUID) magnetometer.

\subsection{Synthesis of $\left[\mathrm{Cu}_{4}(\mathrm{bpy})_{4}(\mathrm{OH})_{4}\left(\mathrm{H}_{2} \mathrm{O}\right)(\mathrm{BTC})\right] \mathrm{NO}_{3} \cdot 8 \mathrm{H}_{2} \mathrm{O}$}

A mixture of $\mathrm{Cu}\left(\mathrm{NO}_{3}\right)_{2} \cdot 3 \mathrm{H}_{2} \mathrm{O}(238 \mathrm{mg}, 1 \mathrm{mmol})$, bpy $(96 \mathrm{mg}, 0.5 \mathrm{mmol})$ in $15 \mathrm{~mL} \mathrm{EtOH}$, was stirred 30 mins, and then a solution of $\mathrm{H}_{3} \mathrm{BTC}(0.2 \mathrm{mmol}, 0.034 \mathrm{~g})$ in aqueous ammonia ( $25 \%$, $10 \mathrm{~mL}$ ) were added dropwise. Filtered and kept the deep blue solution in the dark at room temperature for 10 days. Blue block-shaped crystals were obtained in $38 \%$ yield (based on $\mathrm{Cu}$ ). Elemental analysis (\%): Calcd. for $\mathrm{C}_{49} \mathrm{H}_{57} \mathrm{Cu}_{4} \mathrm{~N}_{9} \mathrm{O}_{22}$ : C, 42. 70; H, 4.17; N, 9.15. Found: C, 42.83; H, 4.13; N, 9.09 .

\subsection{X-ray Crystallographic structure determination}

The X-ray diffraction data was collected using a Bruker APEX-II CCD diffractometer with graphite-monochromated Mo-K $\alpha$ radiation. Structure was solved by direct methods using SHELXTL and refined by full-matrix least-squares on $F^{2}$ using SHELX-97 programs $[22,23]$. Non-hydrogen atoms were refined with anisotropic displacement parameters. All hydrogen atoms were placed by geometrical considerations and were added to the structure factor calculation. However, although the single structure was solved in the chiral P1 space group, the Flack value of 0.389(9) indicated the $\mathbf{1}$ should be the racemic twining crystal. The crystallographic data of 
compound $\left[\mathrm{Cu}_{4}(\mathrm{bpy})_{4}(\mathrm{OH})_{4}\left(\mathrm{H}_{2} \mathrm{O}\right)(\mathrm{BTC})\right] \mathrm{NO}_{3} \cdot 8 \mathrm{H}_{2} \mathrm{O}$ are shown in Table 1 . Selected bond angles and lengths are listed in Table 2.

\section{Results and Discussion}

\subsection{Description of the Structure}

Single crystal X-ray analysis reveals that $\mathbf{1}$ crystallizes in the triclinic system with the chiral P1 (No.1) spacegroup. The asymmetric unit is composed of $\left[\mathrm{Cu}_{4}(\mathrm{bpy})_{4}(\mathrm{OH})_{4}\left(\mathrm{H}_{2} \mathrm{O}\right)(\mathrm{BTC})\right]^{+}$cation, one $\mathrm{NO}_{3}{ }^{-}$anion as counter-ion, along with eight lattice water molecules. The identical chair-like $\left[\mathrm{Cu}_{4}\left(\mu_{3}-\mathrm{OH}\right)_{2}\left(\mu_{2}-\mathrm{OH}\right)_{2}\right]$ core has been observed in the reported analogues compounds. As depicted in Figure 1, both centre $\mathrm{Cu}(\mathrm{II})$ ions $(\mathrm{Cu} 1$ and $\mathrm{Cu} 3)$ are square pyramidal coordination spheres with two $\mathrm{N}$ atoms of bpy, two $\mathrm{O}$ atom from $-\mathrm{OH}$ in the equatorial plane while one $\mathrm{O}$ atom from $\mu_{3}-\mathrm{OH}$ occupied the axial position. The distances of $\mathrm{Cu}-\mathrm{N}$ are about $2 \AA$, while the range of $\mathrm{Cu}-\mathrm{O}$ bond lengths are 1.904(3)-2.434(4) $\AA$ for Cu1 or 1.934(3)-2.288(4) $\AA$ for Cu3, respectively. The equatorial plane of both terminal $\mathrm{Cu}$ (II) ions $(\mathrm{Cu} 2$ and $\mathrm{Cu} 4)$ are also coordinated by two $\mathrm{N}$ atoms of bpy, two $\mathrm{O}$ atoms of $\mu$-OH. The $\mathrm{Cu}-\mathrm{O}$ bond lengths are in the region of 1.928(4)-1.958(3) $\AA$. It is intriguing that the axial terminal ligands of both terminal $\mathrm{Cu}$ (II) are different: an aqua for $\mathrm{Cu} 2$ with the $\mathrm{Cu} 2-\mathrm{O} 1 \mathrm{~W}$ length of 2.227(4) $\AA$, while $\mathrm{BTC}^{3-}$ for $\mathrm{Cu} 4$ with the $\mathrm{Cu} 4-\mathrm{O} 5$ length of 2.237(4) $\AA$. In contrast to the reported orthodox $\mathrm{Cu}_{4}(\mathrm{OH})_{4}$ core analogues ended with same terminal coordination groups in the central symmetric P-1 space group, the result indicates that $\left[\mathrm{Cu}_{4}(\mathrm{bpy})_{4}(\mathrm{OH})_{4}\left(\mathrm{H}_{2} \mathrm{O}\right)(\mathrm{BTC})\right] \mathrm{NO}_{3} \cdot 8 \mathrm{H}_{2} \mathrm{O}(\mathbf{1})$ is a rare asymmetric example of hydroxyl-bridged chair-like tetra-copper complex in chiral P1 space group.

As the Zheng's reported, the hydroxyl-bridged chair-like $\mathrm{Cu}_{4}(\mathrm{OH})_{4}$ core could be considered as the trans-assembly dimerization of two identical dinuclear $\left[\mathrm{Cu}\left(\mu_{2}-\mathrm{OH}\right)_{2} \mathrm{Cu}\right]$ motifs via head-to-tail connection through the out-of-plane $\mathrm{Cu}-\mathrm{O}(\mathrm{H})$ bonds $[18,19]$ rather than the cubane $\mathrm{Cu}_{4}(\mathrm{OH})_{4}$ core cis-assembly via face-to-face connection[24,25]. Therefore, the corresponding parameters are identical for the symmetric dimmerized orthodox $\mathrm{Cu}_{4}(\mathrm{OH})_{4}$ core analogues. However, the parameters of $\left[\mathrm{Cu}\left(\mu_{2}-\mathrm{OH}\right)_{2} \mathrm{Cu}\right]$ motifs in compound $\mathbf{1}$ are dissimilar. The distances of $\mathrm{Cu} 1 \cdots \mathrm{Cu} 2$ in one $\left[\mathrm{Cu}\left(\mu_{2}-\mathrm{OH}\right)_{2} \mathrm{Cu}\right]$ motif is $2.907 \AA$, while the $\mathrm{Cu} 3 \cdots \mathrm{Cu} 4$ in another $\mathrm{Cu}_{2}$-motif is $2.899 \AA$. Moreover, it is interesting that the pairs angles of $\mathrm{Cu}-\mathrm{O}-\mathrm{Cu}$ in the two 
$\left[\mathrm{Cu}\left(\mu_{2}-\mathrm{OH}\right)_{2} \mathrm{Cu}\right]$ motifs of the asymmetric $\left[\mathrm{Cu}_{4}(\mathrm{bpy})_{4}(\mathrm{OH})_{4}\left(\mathrm{H}_{2} \mathrm{O}\right)(\mathrm{BTC})\right]$ unit are also slight different, the angles of $\mathrm{Cu} 1-\mathrm{O} 1-\mathrm{Cu} 2$ and $\mathrm{Cu} 1-\mathrm{O} 2-\mathrm{Cu} 2$ are $99.33(17)$ and $94.81(15)^{\circ}$ in one $\left[\mathrm{Cu}\left(\mu_{2}-\mathrm{OH}\right)_{2} \mathrm{Cu}\right]$ motif, or those of $\mathrm{Cu} 3-\mathrm{O} 3-\mathrm{Cu} 4$ and $\mathrm{Cu} 3-\mathrm{O} 4-\mathrm{Cu} 4$ are $96.06(17)$ and $97.32(17)^{\circ}$ in another $\mathrm{Cu}_{2}$-motif, respectively. The key reason might be the structural distortion derived from the both terminal $\mathrm{Cu}(\mathrm{II})$ coordinated with different spatial size axial ligands $\left(\mathrm{H}_{2} \mathrm{O}\right.$ or $\left.\mathrm{BTC}^{3-}\right)$ to form an asymmetric chair-like $\left[\left(\mathrm{H}_{2} \mathrm{O}\right) \mathrm{Cu}_{4}(\mathrm{OH})_{4}(\mathrm{BTC})\right]$ core.

The full deprotoned $\mathrm{BTC}^{3-}$, plays not only a mono-dentate co-ligand to coordinate $\mathrm{Cu} 4$ via one carboxyl $\mathrm{O}$ atom, but also as acceptors through $\mathrm{O}$ atoms form uncoordinated carboxylate group to connect the hydrogen bonds with coordinated $\mu-\mathrm{OH}$ and water molecule. As depicted in Figure 2a, the $\mathrm{O} 6$ of the carboxylate from $\mathrm{BTC}^{3-}$ forms one intramolecular hydrogen bond with the coordinated $\mu_{3}-\mathrm{OH}$ (the distance of $2.834 \AA$ and the $\angle \mathrm{O} 3-\mathrm{H} 3 \mathrm{~A} \cdots \mathrm{O} 6=118.7^{\circ}$ ). On other hand, the one coordinated $-\mathrm{OH}$ and one aqua form two intermolecular hydrogen bonds with one carboxyl segment from a adjacent $\mathrm{Cu}_{4}$-units (the distance of $2.707 \AA$ and the $\angle \mathrm{O} 1 \mathrm{~W}-\mathrm{H} 1 \mathrm{~Wb} \cdots \mathrm{O} 7 \mathrm{~b}=165.7^{\circ}$, or the distance of $2.814 \AA$ and the $\angle \mathrm{O} 1-\mathrm{H} 1 \mathrm{~A} \cdots \mathrm{O} 8 \mathrm{~b}=117.2^{\circ}$, respectively), while another coordinated $\mu_{2}-\mathrm{OH}$ and $\mu_{3}-\mathrm{OH}$ form two intermolecular hydrogen bonds with one carboxyl segment from another adjacent $\mathrm{Cu}_{4}$-units (the distance of $2.750 \AA$ and the $\angle \mathrm{O} 4 \mathrm{~A}-\mathrm{H} 4 \mathrm{~A} \cdots \mathrm{O} 9 \mathrm{a}=$ $126.0^{\circ}$, or the distance of $2.915 \AA$ and the $\angle \mathrm{O} 2-\mathrm{H} 2 \mathrm{~A} \cdots \mathrm{O} 10 \mathrm{a}=160.6^{\circ}$, respectively). Through the hydrogen bonds, the $\left[\left(\mathrm{H}_{2} \mathrm{O}\right) \mathrm{Cu}_{4}(\mathrm{OH})_{4}(\mathrm{BTC})\right]^{+}$cores were constructed a cation supramolecular layer with hexagonal hollows, which are filled with $\mathrm{NO}_{3}{ }^{-}$counter-ions and eight lattice water molecules. Considered the coordination and $\mathrm{H}$-bonds, each $\mathrm{Cu}_{4}(\mathrm{OH})_{4}(\mathrm{bpy})_{4}$ segment and $\mathrm{BTC}^{3-}$ can be both considered as the 3-connected nodes. Therefore, compound $\mathbf{1}$ can be simplified into the two-dimensional honeycomb networks with $(6,3)$ topology (Fig. 3). Moreover, the pyridyl fragment of bpy molecules are aslant anchored on both outsides of the supramolecular layer. The resulting layers are further packed in slanted $A B$ style interactive stacking to construct a 3-D supramolecular architecture through the interdependently embedded bpy rings, which are resulted from the strong interlayer $\pi-\pi$ stacking interactions between the adjacent bpy planes with the closest with the mean stacking distance of 3.46-3.65 ̊.

\subsection{Thermal Analysis}


Thermogravimetric analyses for $\left[\mathrm{Cu}_{4}(\mathrm{bpy})_{4}(\mathrm{OH})_{4}\left(\mathrm{H}_{2} \mathrm{O}\right)(\mathrm{BTC})\right] \mathrm{NO}_{3} \cdot 8 \mathrm{H}_{2} \mathrm{O}$ has been measured under a flow of $\mathrm{N}_{2}$ gas from room temperature to $750{ }^{\circ} \mathrm{C}$ at a heating rate of $10{ }^{\circ} \mathrm{C} / \mathrm{min}$. Differential scanning calorimetry (DSC) behavior presents one broad absorption heat peak during 30 to $160{ }^{\circ} \mathrm{C}$, and two weak absorption peaks at 190 and $217{ }^{\circ} \mathrm{C}$, respectively, which indicate the corresponding physical (dehydration) or chemical reactions (decomposing). The TGA of the as-synthesized sample showed gradual loss of 12.8 wt\% (calcd: $11.76 \%$ ) from below $160{ }^{\circ} \mathrm{C}$ which belongs to the loss of eight lattice and one coordinated water molecules per $\left[\mathrm{Cu}_{4}(\mathrm{bpy})_{4}(\mathrm{OH})_{4}\left(\mathrm{H}_{2} \mathrm{O}\right)(\mathrm{BTC})\right] \mathrm{NO}_{3} \cdot 8 \mathrm{H}_{2} \mathrm{O}$ formula unit, and then the weight was raipdly lost (42.1\%) with further raising the temperature to $310^{\circ} \mathrm{C}$ which matches the expected value of 45.3 wt\% for the removal of four bpy molecules. Upon $500{ }^{\circ} \mathrm{C}$ the final decomposed residue presumably is $\mathrm{Cu}_{2}(\mathrm{OH})_{2} \mathrm{CO}_{3}$ with the $34.3 \mathrm{wt} \%$ remaining mass (calcd: $32.1 \%$ based on $\mathrm{Cu}$ ).

\subsection{Magnetic Properties}

Variable-temperature magnetic properties of $\left[\mathrm{Cu}_{4}(\mathrm{bpy})_{4}(\mathrm{OH})_{4}\left(\mathrm{H}_{2} \mathrm{O}\right)(\mathrm{BTC})\right] \mathrm{NO}_{3} \cdot 8 \mathrm{H}_{2} \mathrm{O}$ have been studied with a magnetic field of 1000 Oe under normal pressure in the region of $2-300 \mathrm{~K}$. As shown in Figure 3, the magnetic behavior of title compound is illustrated in the form of $\chi_{\mathrm{M}}$ vs. $T$ and $\chi_{\mathrm{M}} T$ vs. $T$ plots. At room temperature, the $\chi_{\mathrm{M}} T$ value of $1.59 \mathrm{~cm}^{3} \mathrm{~mol}^{-1} \mathrm{~K}$ is slightly higher than the expected value of $1.50 \mathrm{~cm}^{3} \mathrm{~mol}^{-1} \mathrm{~K}$ for four uncoupled $S=1 / 2 \mathrm{Cu}$ (II) centers with a $g$ value of 2.0 [26]. Upon cooling to $12 \mathrm{~K}$, the $\chi_{\mathrm{M}} T$ values decrease gradually to $1.408 \mathrm{~cm}^{3} \mathrm{~mol}^{-1} \mathrm{~K}$, along with a slight floating of $1.418 \mathrm{~cm}^{3} \mathrm{~mol}^{-1} \mathrm{~K}$ at $11 \mathrm{~K}$ (insert in Figure 3), and then sharply drop down to a minimum of $1.15 \mathrm{~cm}^{3} \mathrm{~mol}^{-1} \mathrm{~K}$ at $2 \mathrm{~K}$. The $1 / \chi_{\mathrm{M}}$ versus $T$ plot can be well-fitted by the Curie-Weiss law above $30 \mathrm{~K}$, giving a Weiss constant of -21.1(1) K (see Figure S5). The negative $\theta$ value indicates the dominant antiferromagnetic exchanges within $\mathrm{Cu}_{4}(\mathrm{OH})_{4}$ cluster.

Besides the long distance of $\mathrm{Cu} \cdots \mathrm{Cu}$ within H-bond layer $(10.87$ and $11.21 \AA$ ) or $\mathrm{Cu} \cdots \mathrm{Cu}$ separated by $\pi-\pi$ staking (11.83 $\AA$ ), the structural distortion (as mentioned above and see Figure 4 ) leads to the magnetic coupling parameters in the isotropic asymmetric $\mathrm{Cu}_{4}$-unit are still too complicated to be evaluated. It has been assumed the absence of magnetic interaction between the terminal $\mathrm{Cu}$ (II) ions $\left(\mathrm{Cu} 2 \cdots \mathrm{Cu} 4\right.$ above $5.55 \AA$ ) and the long sides of butter-fly $\mathrm{Cu}_{4}$-unit $(\mathrm{Cu} 1 \cdots \mathrm{Cu} 4$ and $\mathrm{Cu} 2 \cdots \mathrm{Cu} 3)$ due to the relatively larger separation. Hence, the experimental $\chi_{\mathrm{M}} T$ data had to be fitted using the modified analytical express equation being used in study of the 
zigzag linear tetranuclear system $[18,27]$, which is derived from Heisenberg-Dirac-vanVleck (HDVV) spin Hamiltonian model $\hat{H}=-2 J_{a}\left(\hat{S}_{1} \cdot \hat{S}_{2}+\hat{S}_{3} \cdot \hat{S}_{4}\right)-2 J_{b} \hat{S}_{1} \cdot \hat{S}_{3}$. The $J_{a}$ or $J_{b}$ represent the distinct superexchange coupling between two $\mathrm{Cu}(\mathrm{II})$ atoms of intra- or inter-dimmer $\left[\mathrm{Cu}\left(\mu_{2}-\mathrm{OH}\right)_{2} \mathrm{Cu}\right]$ motifs, respectively. Taking into account the TIP term, the best fit parameters to the magnetic data were found to be $J_{\mathrm{a}}=-0.27 \mathrm{~cm}^{-1}, J_{\mathrm{b}}=0.09 \mathrm{~cm}^{-1}, g=1.96$ and TIP $=4.70 \times 10^{-4}$, which are different from that of hydroxo-bridged symmetric compounds, with positive $J_{\mathrm{a}}$ and $J_{\mathrm{b}}$ that indicated the ferromagnetic coupling within $\mathrm{Cu}_{4}(\mathrm{OH})_{4}$ core [18].

\section{Conclusions}

In conclusion, we have successfully prepared an unprecedented tetra-copper compound based on asymmetric chair-like hydroxo-bridged $\left[\mathrm{Cu}_{4}(\mathrm{bpy})_{4}(\mathrm{OH})_{4}\left(\mathrm{H}_{2} \mathrm{O}\right)(\mathrm{BTC})\right]$ cores, where the terminal ligands are coordinated aqua and deprotoned $\mathrm{BTC}^{3-}$, respectively. Through the hydrogen bonds between the $\mathrm{BTC}^{3-}$ and coordination $-\mathrm{OH} / \mathrm{H}_{2} \mathrm{O}$, the compound 1 forms the honeycomb supramolecular layer. The overall varial-temperature magnetic behavior of this compound indicates the predominant antiferromagnetic coupling inside the chair-like $\mathrm{Cu}_{4}(\mathrm{OH})_{4}$ magnetic unit.

\section{Acknowledgements}

This work was financially supported by the National Science Foundation of China (Grant No. 11375082, 11275090 and 11175080) and the Scientific Research Foundation for the Returned Overseas Chinese Scholars, State Education Ministry (SRF for ROCS, SEM to Dr. X. W.).

\section{Appendix A. Supplementary material}

Crystallographic data for the structural analysis have been deposited at the Cambridge Crystallographic Data Centre, CCDC No 1486080. These data can be obtained free of charge via http://www.ccdc.cam.ac.uk/conts/retrieving.html, or from the CCDC, 12 Union Road, Cambridge, CB2 1EZ, UK: fax: (+44) 01223-336-033; e-mail: deposit@ccdc.cam.ac.

Supplementary data associated with this article can be found, in the online version, at http://dx.doi.org/ 


\section{References}

[1] C. J. Brown, F. D. Toste, R. G. Bergman, K. N. Raymond, Chem. Rev. 2015, 115, 3012-3035.

[2] H. -B. Xu, X. -M. Chen, Q. -S. Zhang, L. -Y. Zhang, Z. -N. Chen, Chem. Commun. 2009, $7318-7320$.

[3] X. -F. Wang, X. -L. Qi, F. -N. Shi, J. Rocha, J. Mol. Struct. 2011, 1004, 26-30.

[4] M. Kiguchi, J. Inatomi, Y. Takahashi, R. Tanaka, T. Osuga, T. Murase, M. Fujita, T. Tada, S. Watanabe, Angew. Chem. Int. Ed. 2013, 52, 6202-6205.

[5] C. M. Zaleski, S. Tricard, E. C. Depperman, W. Wernsdorfer, T. Mallah, M. L. Kirk, V. L. Pecoraro, Inorg. Chem. 2011, 50, 11348-11352.

[6] W.-X. Zhang,Y.-Y. Yang, S.-B. Zai, S. W. Ng, X.-M. Chen, Eur. J. Inorg. Chem. 2008, 679-685.

[7] B. Berkoff, K. Griffiths, A. Abdul-Sada, G. J. Tizzard, S. J. Coles, A. Escuer, G. E. Kostakis, Dalton Trans. 2015, 44, 12788-12795.

[8] T. Liu, Y.-J. Zhang, Z.-M. Wang, S. Gao, J. Am. Chem. Soc. 2008, 130, 10500-10501.

[9] A. J. Tasiopoulos, W. Wernsdorfer, K. A. Abboud, G. Christou, Angew. Chem. Int. Ed. 2004, 43, 6338-6342.

[10] D. I. Alexandropoulos, T. N. Nguyen, L. Cunha-Silva, T. F. Zafiropoulos, A. Escuer, G. Christou, T. C. Stamatatos, Inorg. Chem. 2013, 52, 1179-1183.

[11] P.-P. Yang, X.-F. Gao, H.-B. Song, S. Zhang, X.-L. Mei, L.-C. Li, D.-Z. Liao, Inorg. Chem. 2011, 50, 720-722.

[12] M.-H. Zeng, M.-X. Yao, H. Liang, W.-X. Zhang, X.-M. Chen, Angew. Chem. Int. Ed. 2007, 46, 1832-1835.

[13] Y.-Z. Zheng, M. Speldrich, H. Schilder, X.-M. Chen, P. Kögerler, Dalton Trans. 2010, 39, $10827-10829$.

[14] F. He, M.-L. Tong, X.-L. Yu, X.-M. Chen, Inorg. Chem. 2005, 44, 559-565.

[15] A. J. Tasiopoulos, W. Wernsdorfer, K. A. Abboud, G. Christou, Polyhedron 2005, 24, $2505-2512$.

[16] R. Dey, B. Bhattacharya, E. Colacio, D. Ghoshal, Dalton Trans. 2013, 42, 2094-2016.

[17] A. Hazra, S. Bonakala, K. K. Bejagam, S. Balasubramanian, T. K. Maji, Chem. Eur. J. 2016, 22, $7792-7799$.

[18] Y. -Q. Zheng, D. -Y. Cheng, B. -B. Liu, W. -X. Huang, Dalton Trans. 2011, 40, 277-286.

[19] X. Li, D.-Y. Cheng, J. -L. Lin, Z.-F. Li, Y. -Q. Zheng, Cryst. Growth Des. 2008, 8, $2853-2861$

[20] S. Balboa, R. Carballo, A. Castineiras, J. M. Gonzalez-Perez, J. Niclos-Gutierrez, Polyhedron 2008, 27, 2921-2930.

[21] J. -H. Luo, L. Chen, C. -Y. Yue, F. -L. Jiang, M. -C. Hong, Jiegou Huaxue (Chin. J. Struct. Chem.) 2007, 26, 654-658.

[22] G. M. Sheldrick, SHELXS-97, Program for the Solution of Crystal Structures, Göttingen, Germany, 1997.

[23] G. M. Sheldrick, SHELXL-97, Program for the Refinement of Crystal Structures, Göttingen, Germany, 1997.

[24] J. Sletten, A. Sørensen, M. Julve, Y. Journaux, Inorg. Chem. 1990, 29, 5054-5058.

[25] R. Carballo, B. Covelo, E. M. Vazquez-Lopez, E. Garcia-Martinez, A. Castineiras, Z. Anorg. Allg. Chem. 2002, 628, 907-908.

[26] S. R. Breeze, S. Wang, J. E. Greedan, N. P. Raju, J. Chem. Soc., Dalton Trans. 1998, 2327-2334.

[27] C. Zeng, Y. Zang, G. Wang, A. Dai, Acta Chim. Sinica, 1990, 48, 678-685 . 


\section{The Tables and Figures Captions}

Table 1

Crystallographic data and structure refinement of $\left[\mathrm{Cu}_{4}(\mathrm{bpy})_{4}(\mathrm{OH})_{4}\left(\mathrm{H}_{2} \mathrm{O}\right)(\mathrm{BTC})\right] \mathrm{NO}_{3} \cdot 8 \mathrm{H}_{2} \mathrm{O}$.

Table 2

Selected bond lengths $(\AA)$ and angles $\left(^{\circ}\right)$ in $\left[\mathrm{Cu}_{4}(\text { bpy })_{4}(\mathrm{OH})_{4}\left(\mathrm{H}_{2} \mathrm{O}\right)(\mathrm{BTC})\right] \mathrm{NO}_{3} \cdot 8 \mathrm{H}_{2} \mathrm{O}^{\mathrm{a}}$.

Figure 1

The coordination environment of $\mathrm{Cu}(\mathrm{II})$ centers in the asymmetric $\mathrm{Cu}_{4}(\mathrm{OH})_{4}$ cation unit. Thermal ellipsoids are drawn at the $30 \%$ probability level. $\mathrm{H}$ atoms of bpy and BTC are omitted for clarity.

Figure 2

(a) The $\mathrm{H}$ bonding motif of the $\mathrm{Cu}_{4}(\mathrm{bpy})_{4}(\mathrm{OH})_{4}$ unit (the segments of bpy rings are omitted for clarity) and (b) The $\pi-\pi$ stacking interactions of bpy rings.

Figure 3

(a) The planform view of the honeycomb-like H-bond layer structure with cavities (marked with yellow oval); (b) $\mathrm{Cu}_{4}(\mathrm{bpy})_{4}(\mathrm{OH})_{4}$ or BTC $^{3-}$ respectively as two different three connected $\mathrm{H}$-bond nodes; (c) the $(6,3)$ topological net, (d) The side view of the H-bond layer and (e) the space-filled presentation of the slide $\mathrm{AB}$ style packing of adjacent layers.

Figure 4

The TGA and DSC curves for $\left[\mathrm{Cu}_{4}(\mathrm{bpy})_{4}(\mathrm{OH})_{4}\left(\mathrm{H}_{2} \mathrm{O}\right)(\mathrm{BTC})\right] \mathrm{NO}_{3} \cdot 8 \mathrm{H}_{2} \mathrm{O}$.

Figure 5

The $\chi_{\mathrm{M}} T(\circ)$ and $\chi_{\mathrm{M}}(\square)$ vs $T$ plots for $\mathbf{1}$ (insert the low temperature region). The red solid lines are the fits of the data.

Figure 6

Coupling scheme for the tetranuclear $\mathrm{Cu}_{4}(\mathrm{OH})_{4}$ unit. 
Table 1. Crystallographic data for $\mathbf{1}$.

\begin{tabular}{|c|c|}
\hline Empirical formula & $\mathrm{C}_{49} \mathrm{H}_{57} \mathrm{Cu}_{4} \mathrm{~N}_{9} \mathrm{O}_{22}$ \\
\hline Formula weight & 1378.24 \\
\hline Temperature & $296(2)$ \\
\hline Crystal system & Triclinic \\
\hline space_group & $P 1$ \\
\hline \multirow[t]{6}{*}{ Unit cell dimensions } & $a=10.3896(4) \AA$ \\
\hline & $b=12.5152(5) \AA$ \\
\hline & $c=12.8954(5)$ \\
\hline & $\alpha=115.252(2)^{\mathrm{o}}$ \\
\hline & $\beta=99.823(2)^{\circ}$ \\
\hline & $\gamma=104.892(2)^{\circ}$ \\
\hline Volume/ $\AA^{3}$ & $1388.22(9)$ \\
\hline$Z$ & 1 \\
\hline$D_{\text {calc. }} / \mathrm{g} \cdot \mathrm{cm}^{-3}$ & 1.649 \\
\hline Absorpt coefficient $/ \mathrm{mm}^{-1}$ & 1.600 \\
\hline$F(000)$ & 706 \\
\hline$R_{\text {int }}$ & 0.022 \\
\hline Reflections collected & 22888 \\
\hline Independent reflections & 10963 \\
\hline Observed reflections $[I>2 \sigma(I)]$ & 10023 \\
\hline Refinement method & Full-matrix least-squares on $F^{2}$ \\
\hline Number of parameters & 753 \\
\hline Goodness-of-fit on $F^{2}$ & 1.041 \\
\hline Final $R$ indices $[I>2 \sigma(I)]$ & $R_{1}=0.0326, w R_{2}=0.0910$ \\
\hline$R$ indices (all data) & $R_{1}=0.0366, w R_{2}=0.0937$ \\
\hline$\Delta \rho_{\max }\left(\mathrm{e} \cdot \AA^{-3}\right)$ & 0.541 \\
\hline$\Delta \rho_{\min }\left(\mathrm{e} \cdot \AA^{-3}\right)$ & -0.585 \\
\hline
\end{tabular}


Table 2 Selected bond lengths $(\AA)$ and angles $\left(^{\circ}\right)$ for $1^{\text {a }}$

\begin{tabular}{l|l||l|l}
\hline $\mathrm{Cu} 1-\mathrm{O} 1$ & $1.905(3)$ & $\mathrm{Cu} 1-\mathrm{O} 2$ & $1.962(4)$ \\
$\mathrm{Cu} 1-\mathrm{N} 1$ & $2.013(4)$ & $\mathrm{Cu} 1-\mathrm{N} 2$ & $1.987(5)$ \\
$\mathrm{Cu} 1-\mathrm{O} 3$ & $2.434(4)$ & & \\
$\mathrm{Cu} 2-\mathrm{O} 1$ & $1.909(4)$ & $\mathrm{Cu} 2-\mathrm{O} 1 \mathrm{~W}$ & $2.230(4)$ \\
$\mathrm{Cu} 2-\mathrm{N} 3$ & $2.014(5)$ & Cu2-N4 & $2.009(4)$ \\
$\mathrm{Cu} 2-\mathrm{O} 2$ & $1.985(3)$ & & \\
$\mathrm{Cu} 3-\mathrm{O} 2$ & $2.288(4)$ & $\mathrm{Cu} 3-\mathrm{O} 3$ & $1.943(4)$ \\
$\mathrm{Cu} 3-\mathrm{N} 5$ & $2.018(5)$ & $\mathrm{Cu} 3-\mathrm{N} 6$ & $2.025(4)$ \\
$\mathrm{Cu} 3-\mathrm{O} 4$ & $1.927(4)$ & & \\
$\mathrm{Cu} 4-\mathrm{O} 3$ & $1.958(3)$ & $\mathrm{Cu} 4-\mathrm{O} 4$ & $1.928(4)$ \\
$\mathrm{Cu} 4-\mathrm{N} 7$ & $2.010(4)$ & $\mathrm{Cu} 4-\mathrm{N} 8$ & $1.999(5)$ \\
$\mathrm{Cu} 4-\mathrm{O} 5$ & $2.239(4)$ & & \\
\hline $\mathrm{Cu} 1-\mathrm{O} 1-\mathrm{Cu} 2$ & $99.29(17)$ & $\mathrm{Cu} 1-\mathrm{O} 2-\mathrm{Cu} 2$ & $94.85(15)$ \\
$\mathrm{Cu} 1-\mathrm{O} 2-\mathrm{Cu} 3$ & $99.63(17)$ & $\mathrm{Cu} 1-\mathrm{O} 3-\mathrm{Cu} 3$ & $95.41(16)$ \\
$\mathrm{Cu} 1-\mathrm{O} 3-\mathrm{Cu} 4$ & $105.82(15)$ & $\mathrm{Cu} 2-\mathrm{O} 2-\mathrm{Cu} 3$ & $109.14(16)$ \\
$\mathrm{Cu} 3-\mathrm{O} 3-\mathrm{Cu} 4$ & $96.01(16)$ & $\mathrm{Cu} 3-\mathrm{O} 4-\mathrm{Cu} 4$ & $97.35(17)$ \\
\hline
\end{tabular}

a) The numbering scheme is shown in Figure 1 . 


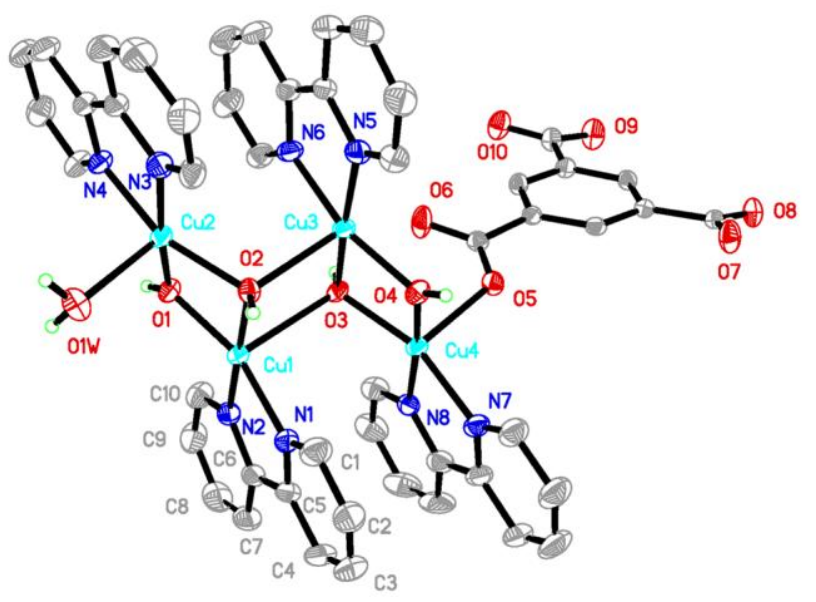

Figure 1.

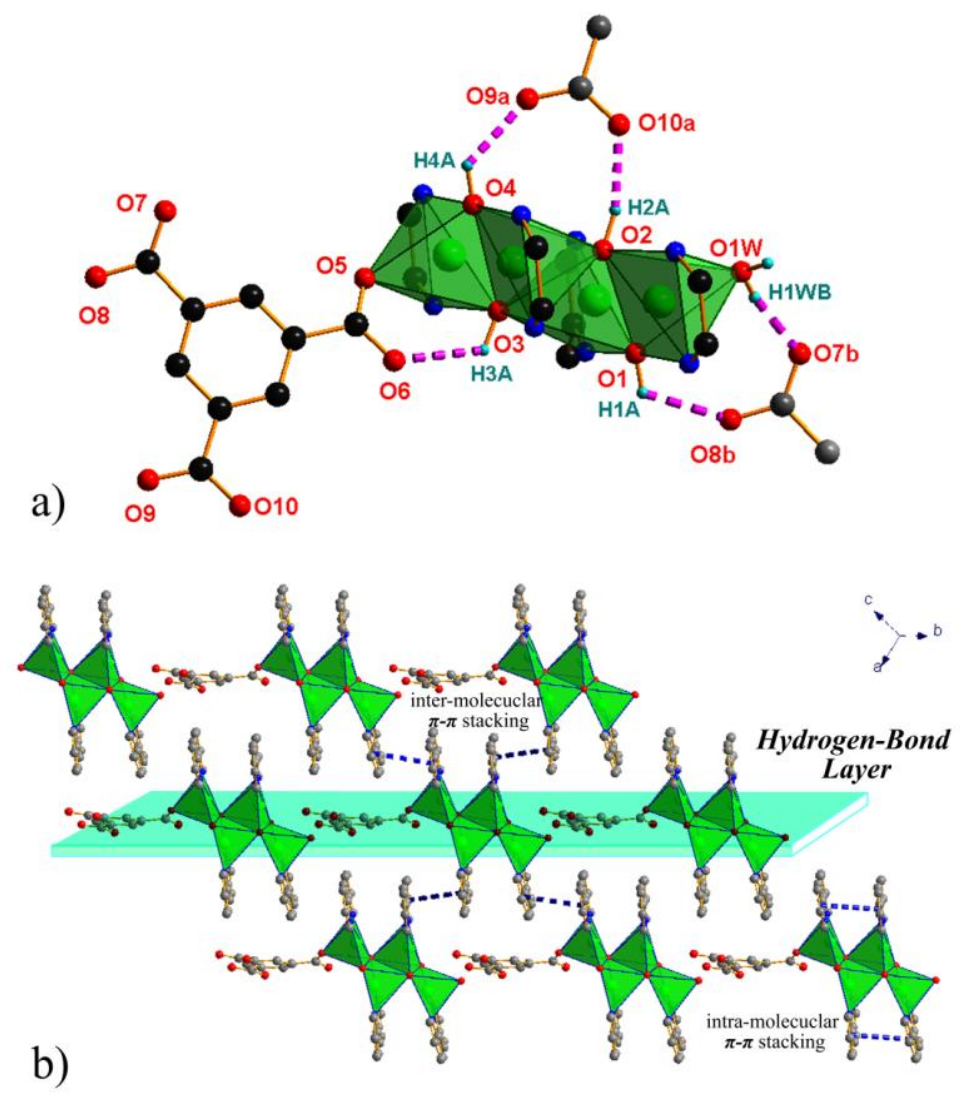

Figure 2. 


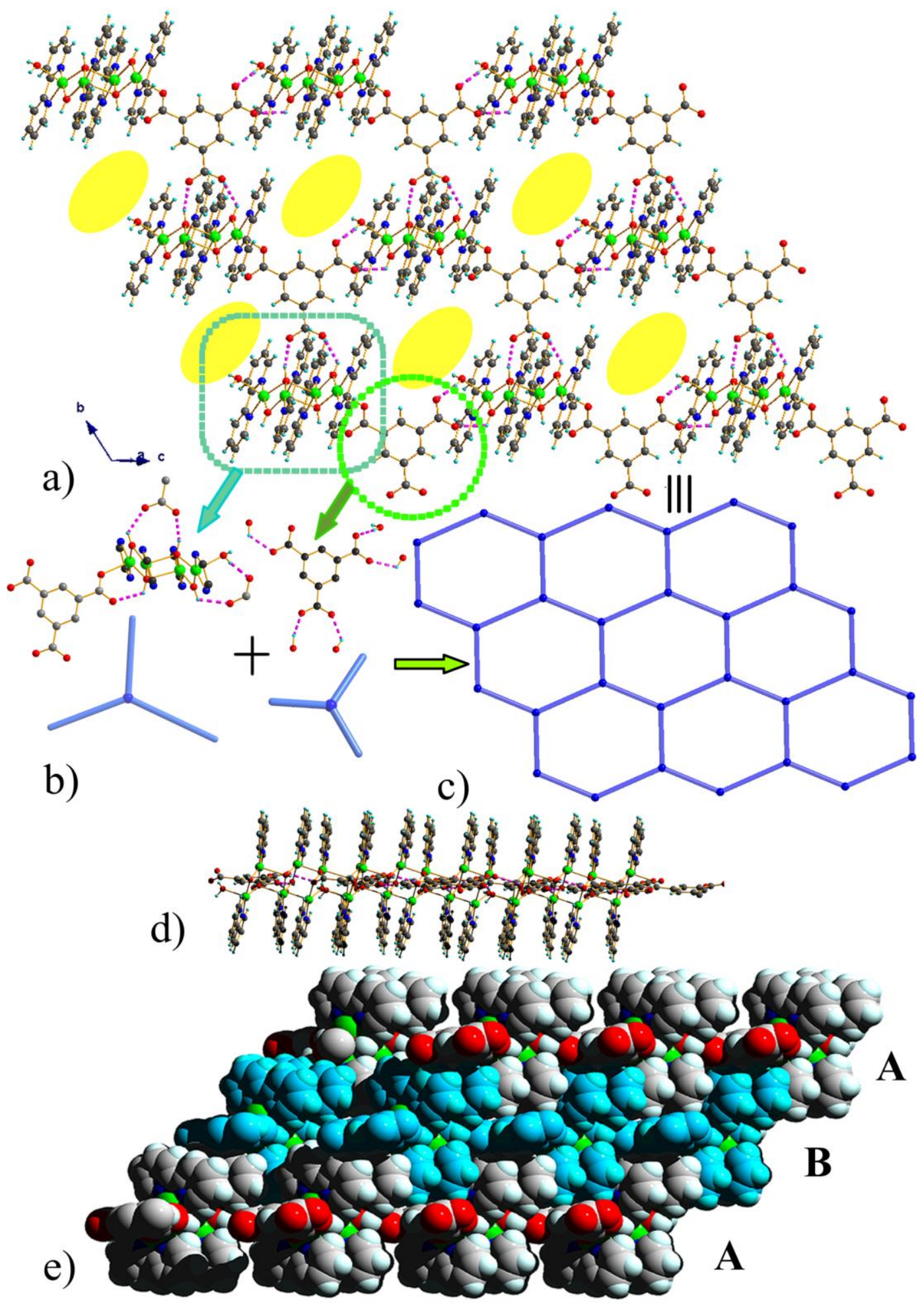

Figure 3. 


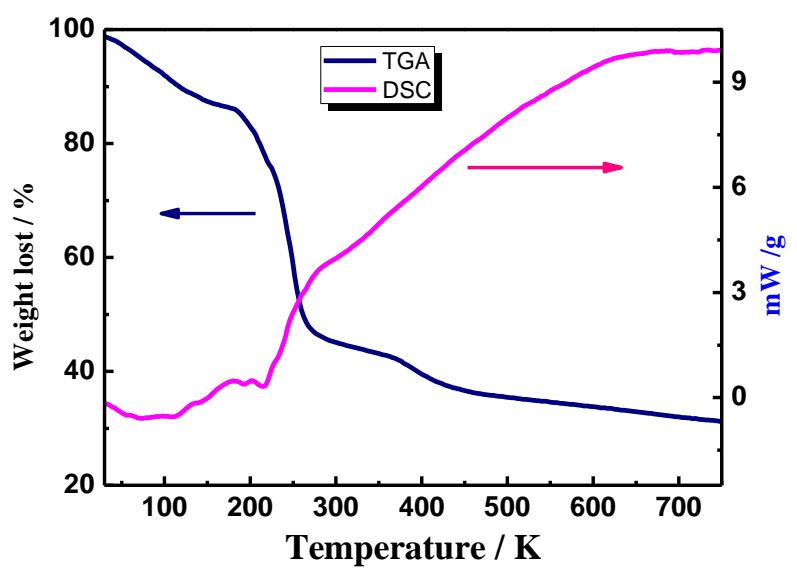

Figure 4.

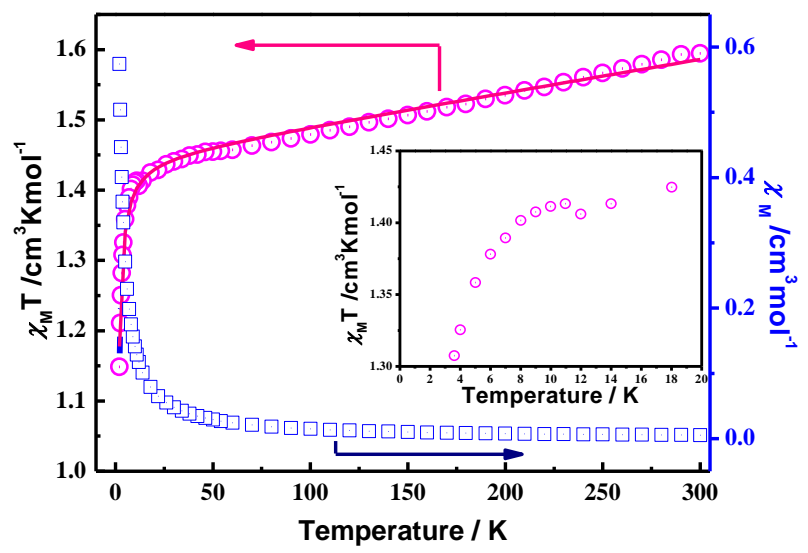

Figure 5.

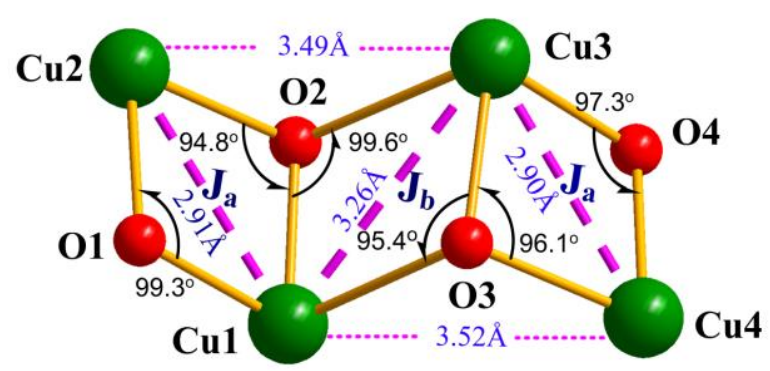

Figure 6. 
Graphical Abstract

A copper complex based on the asymmetric chair-like hydroxo-bridged tetra-copper $\left[\mathrm{Cu}_{4}(\mathrm{bpy})_{4}(\mathrm{OH})_{4}\left(\mathrm{H}_{2} \mathrm{O}\right)(\mathrm{BTC})\right]$ units has been synthesized and characterized. In addition, the magnetic property of the compound was investigated.

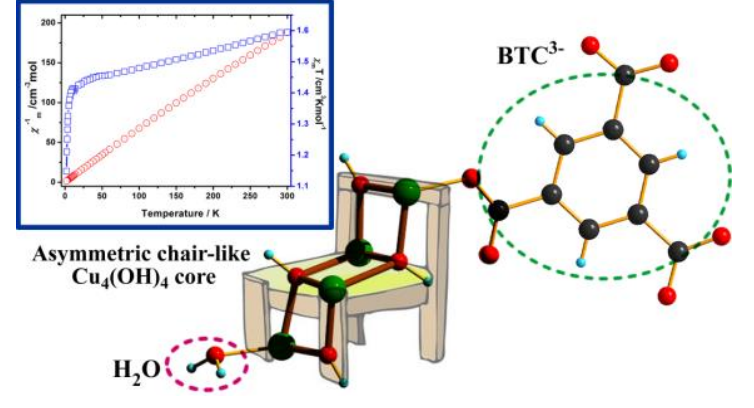

Xiao-Feng Wang, * Ke-Jie Du, Hong-Qing Wang, Xue-Li Zhang* and Chang-Ming Nie

An Novel Asymmetric

Chair-like Hydroxyl-bridged Tetra-copper Compound:

Synthesis, Supramolecular

Structure and Magnetic

Property 